\title{
The correlation between facial esthetics and social psychology from orthodontic perspective
}

\author{
Corelaţia între estetica facială şi psihologia socială, \\ din perspectivă ortodontică
}

Aurelia Magdalena Enache
Disciplina de Ortodonţie şi Ortopedie Dento-facială, Facultatea de Medicină Dentară,
Universitatea de Medicină şi Farmacie „Carol Davila“, Bucureşti,România

\begin{abstract}
It is known that there is a strong correlation between orthodontics and social psychology. The effect of the orthodontic treatment on facial aesthetics has an important impact on attractiveness and personality of the patient. This correlation should be taken into consideration in all the phases of the orthodontic treatment: patient exam and problem list, treatment planning and type of orthodontic appliance, assessment of the orthodontic treatment. The evaluation of the orthodontic treatment results is different for the doctor and the patient and has led to a change of the paradigm, that of the soft tissues, which puts aesthetic and functional positions equally for the establishment of the treatment plan and for its evaluation.
\end{abstract}

Keywords: facial aesthetics, orthodontics, social psychology, attractive

\section{REZUMAT}

Este cunoscut faptul că există o strânsă corelaţie între ortodonţie şi psihologie, tratamentul ortodontic având un impact important asupra esteticii faciale, care, la rândul ei, este în corelaţie directă cu atractivitatea şi influenţează profilul psihologic al pacientului. Această corelaţie dintre cele două specialităţi trebuie avută în vedere în toate fazele tratamentului ortodontic: examinarea pacientului şi determinarea obiectivelor tratamentului ortodontic, stabilirea planului de tratament şi alegerea aparatului ortodontic, evaluarea rezultatului tratamentului ortodontic.

Evaluarea rezultatelor tratamentului ortodontic este diferită pentru medic şi pacient şi a dus la o schimbare de paradigmă, aceea a ţesuturilor moi, care pune pe poziţii egale estetica şi funcţionalitatea atât pentru stabilirea planului de tratament, cât şi pentru evaluarea acestuia.

Cuvinte cheie: estetică facială, ortodonţie, psihologie socială, atractivitate

Anomaliie dento-maxilare reprezintă o importantă problemă de sănătate, justificată atât de epidemiologia acestora, de consecinţele funcționale şi estetice, cât şi de impactul economic, social şi psihologic. Este pe deplin acceptat faptul că majoritatea pacienților solicită tratament ortodontic din motive de ordin estetic şi alţi factori psiho-sociali $(1,2)$, factorul funcțional fiind mai puțin recunoscut de către pacient.

Deşi, aparent, nu există nicio corelaţie între ortodonţie şi psihologie (şi, mai concret, cu psihologia socială, ortodonția fiind o specialitate exactă, care înseamnă un tratament clinic, iar psihologia socială - o ştiință socială), există însă o influență reciprocă. Corelația dintre cele două specialități este importantă în toate fazele tratamentului ortodontic: examinarea pacientului şi determinarea obiectivelor tratamentului ortodontic, stabilirea planului de tratament şi alegerea aparatului ortodontic, evaluarea rezultatului tratamentului ortodontic.

\section{Examenul clinic şi stabilirea obiectivelor de tratament}

O mare parte a elementelor din cadrul examenului clinic în ortodonţie, atât facial, cât şi intraoral, au o importantă deosebită în estetica facială, cu impact în atractivitatea individului, deoarece "beauty 
is in the eyes of the beholder (3)". Astfel, este demonstrat prin numeroase studii (4) faptul că indivizii cu un aspect facial plăcut au relații interpersonale mai favorabile şi, de asemenea, performanțe academice şi ocupaționale mai bune.

Există trei componente distincte ale esteticii faciale ce trebuie luate în considerare în examenul clinic şi care sunt strâns corelate cu impactul psihologic al tratamentului ortodontic (uneori un tratament interdisciplinar) asupra calității vieții individului, şi anume: macroestetica, miniestetica şi microestetica (3).

Diferențiate prin magnitudinea devierii față de normal, macroestetica se referă la față, miniestetica se referă la zâmbet (cunoscut fiind faptul că zâmbetul este a doua trăsătură importantă, după ochi, în aprecierea atractivității individului), iar microestetica apreciază caracteristicile estetice ale dinților şi gingiei.

Astfel, cele mai importante elemente de macroestetică, ce sunt corelate cu dezvoltarea scheletală a aparatului dento-maxilar în cele trei planuri spațiale, sunt simetria facială, profilul facial şi tiparul vertical (proporţia etajelor feței).

a. simetria facială. În medicină, simetria înseamnă echilibru, orice individ având un mic grad de asimetrie facială, care este acceptată ca fiind normală. Aprecierea simetriei în ortodonție se face prin modalități obiective, examen clinic, fotografic şi radiologic (teleradiografie sau CBCT). Sunt situaţii în care o asimetrie facială este mascată de părțile moi sau, deşi la nivel scheletal există simetrie, părțile moi pot avea o dezvoltare sau un comportament asimetric. Rhodes et al. au stabilit că simetria facială are impact important asupra atractivităţii (5), de aceea, în funcție de dorinţele pacientului şi de gravitatea asimetriei, corectarea acesteia poate necesita uneori asocierea tratamentului chirurgical ortognatic.

b. profilul facial. Deşi majoritatea studiilor apreciau atractivitatea doar prin examinare din normă frontală, de la Angle până la McLaughlin, s-a discutat importanța profilului facial în estetica facială şi s-a dovedit că profilul normal este considerat ca fiind cel mai atractiv.

Într-un studiu pe copii cu vârste cuprinse între 10 şi 14 ani, Lucker şi colab. (6) au arătat că şi copiii au sesizat că la profilul convex sau concav este ceva greşit (fără a putea spune ce anume), față de pozele copiilor cu profil normal, subliniind astfel că modificările asupra profilului facial prin tratament ortodontic reprezintă un obiectiv chiar şi pentru copii.

Alessandri Bonetti G. şi colaboratorii (7) au stabilit că discutarea cu pacienții a aspectului profilului pe fotografiile diagnostice înainte de tratament poate reduce discrepanța de percepție asupra rezultatului tratamentului între pacient şi medicul ortodont, deoarece profilul nu este important pentru aceştia în evaluarea propriei atractivităţi faciale, decât atunci când îşi examinează fotografiile din profil.

c. tiparul vertical al feței. Considerând importantă dimensiunea facială verticală asupra atractivităţii şi, deci, impactul psiho-social al acesteia, studiile au arătat că tiparul vertical al feței este foarte important, atât în aprecierea atractivității din normă frontală, cât şi din normă laterală, în egală măsură pentru pacient şi medicul ortodont şi, de asemenea, este un obieciv care creşte solicitarea de tratament ortodontic din partea pacientului (8). Frecvent însă, tratamentul ortodontic singur nu poate corecta dimensiunea verticală a etajului inferior, fiind necesar un tratament chirurgical ortognatic asociat.

Trebuie menționat faptul că atractivitatea depinde şi de aspectul şi dimensiunea buzelor, a nasului şi alte elemente care țin chiar de comportamentul părților moi şi care trebuie examinate în detaliu şi corelate cu ceea ce sesizează pacientul şi ce îşi doreşte acesta.

Examinarea zâmbetului este criteriu de bază pentru miniestetica facială şi numeroase studii au încercat să arate ce înseamnă un zâmbet atractiv: buza inferioară urmăreşte muchiile incizale ale dinților superiori, coridoarele bucale sunt reduse ca dimensiune, sunt vizibili toți dinții frontali şi premolarii şi, de asemenea, este atractiv să fie vizibil şi 1-2 mm din mucoasa gingivală. Orice deviere de la aceste standarde afectează percepția estetică, dar, totuşi, în mod diferit pentru pacienţi şi ortodonţi. Astfel, este cunoscut faptul că înclinarea planului de ocluzie afectează percepția atractivității zâmbetului pentru valori mai mari pentru pacienţi şi la valori mai mici pentru ortodonți (9).

Elementele de microestetică facială sunt cele care, în general, nu sunt evidente pentru pacient şi nu sunt sesizate cu uşurință, dar care trebuie explicate acestuia înainte de tratament, pentru că sunt 
importante în evaluarea rezultatului tratamentului.

După examinarea clinică a pacientului, se stabileşte, ţinând cont şi de motivul pentru care pacientul solicita tratament ortodontic, planul de tratament.

\section{Planul de tratament şi alegerea aparatului ortodontic}

Stabilirea planului de tratament trebuie să țină cont de obiectivele de tratament, de prioritatea acestora şi de dorințele pacientului. De multe ori, obținerea unui rezultat estetic nu se poate realiza doar prin tratament ortodontic şi, în special la adulți, unde creşterea s-a încheiat, este necesar şi tratament chirurgical ortognatic (10). Astfel, şi obiectivele tratamentului chirurgical trebuie adaptate cerinţelor pacientului, pentru că impactul psihologic poate fi greu de suportat, atunci când modificările sunt de amplitudine mare, chiar dacă acestea sunt favorabile.

Alegerea tipului de aparat ortodontic este strâns corelată şi cu impactul psihologic asupra pacientului, iar acest aspect trebuie corelat cu gradul de vizibilitate al aparatului şi cooperarea pacientului în purtarea aparatelor mobile.

Astfel, dacă gradul de vizibilitate al aparatului este un criteriu pentru pacient, în special pentru pacienții adulți cu profesii care implică comunicare şi interacțiune socială, atunci acesta va solicita aparate cât mai fizionomice (aparate fixe cu bracket-uri de ceramică, aparate linguale, invisalign). S-a constatat că pacienții care solicită tratament ortodontic cu aparate linguale sunt mai riguroşi şi mai atenți la detalii. De asemenea, adolescenții sunt o altă categorie care solicită aparate fixe fizionomice, deoarece vizibilitatea aparatului poate scădea încrederea în sine şi poate afecta relațiile sociale ale acestora. $\mathrm{Cu}$ toate acestea, Prado şi colab. au arătat că primele şase luni de tratament ortodontic îmbunătățesc impactul psiho-social al anomaliilor dento-maxilare.

Impactul psiho-social al tratamentului ortodontic, prin tipul de aparat ortodontic, are un rol important şi în cooperarea pacientului în purtarea aparatului, atunci când acesta este mobil. Un pacient dornic să corecteze o anomalie dento-maxilară, din cauza implicațiilor psihologice ale acesteia asupra pacientului-copil (care are o poreclă la şcoală din cauza poziției dinților), va fi mai motivat şi mai cooperant, respectând indicațiile şi durata de purtare a aparatului. Hebert afirmă că succesul tratamentului cu arc facial depinde de motivația pacientului, respectarea duratei de purtare a aparatului, având în vedere că acest aparat este mobilizabil şi implică şi un disconfort mai mare.

\section{Evaluarea rezultatului tratamentului orto- dontic}

Criteriile evaluării rezultatului unui tratament ortodontic din punct de vedere estetic sunt diferite pentru pacient şi medicul ortodont, pacientul apreciind acest rezultat în special prin impactul psihosocial, creşterea calităţii vieții şi raportul cost-beneficiu.

Această situație a făcut să apară o schimbare de paradigmă, de la paradigma funcționalistă, specifică secolului al XX-lea, în care criteriul în stabilirea planului de tratament şi în evaluarea rezultatului era cel funcțional, estetica fiind considerată ca având scop cosmetic, la paradigma țesuturilor moi, care recunoaşte importanţa esteticii faciale asupra calității vieții, prin impactul psiho-social, şi plasează estetica şi funcționalitatea pe poziție de egalitate (11).

\section{CONCLUZII}

În concluzie, putem afirma că există o strânsă corelație între ortodonţie şi psihologie, tratamentul ortodontic având un impact important asupra esteticii faciale, care, la rândul ei, este în corelație directă cu atractivitatea. De aceea, tratamentul ortodontic trebuie să țină cont, în toate etapele lui, de influența pe care o are asupra profilului psihologic al pacientului.

Conflict of interest: none declared Financial support: none declared

\section{BIBLIOGRAFIE}

1. Graber T. et al. Psychological aspects of facial form. Craniofacial Growth Series, Michigan, Ann Arbor, 1980.

2. Aronso E., Wilson T.D., Akert R.M. Social psychology, $3^{\text {rd }}$ edn, New York, Logmand, 1988.
3. Nanda R. Esthetics and Biomechanics in Orthodontics, $2^{\text {nd }}$ edn, Elsevier 2015.

4. Langlois H.R., Kalakanis L.E., Rubenstein A.J., Larson A.D. Maxim or myths of beauty. A meta-analytic and theorethical overview, Psycho Bull 2000. 
5. Rhodes G., Harwood K., Yoshikawa S., Nishitami McLean I. The attractiveness of average faces, cross-cultural evidence and possible biological basis, WESTPORT, Ablex 2002.

6. Lucker G.W., Graber L.W., Pietrimonaco P. The importance of dentofacial appearance in facial esthetics. A signal detection approach. Basic Appl Soc Psychol1981, 2,261-274.

7. Alessandri Bonetti G., Alberti A., Sartini C., Parenti S.I. Patients' self-perception of dentofacial attractiveness before and after exposure to facial photographs, The Angle Orthodontics, May 2011, vol 81, no3, 517-524.
8. Varlik S.K. et al. Influence of lower facial changes on frontal attractiveness and perception of treatment need by lay people.

9. Batwa W., Hunt N., Petrie A., Gill D. Effect of occlusal plane on smole attractiveness, The Angle Orthodontics, vol82, no2, March 2012, 218-223.

10. Sarver D.M. Esthetic orthodontics and orthognathic surgery, St. Louis, Mosby. 1998.

11. Proffit W.R. The soft tissue paradigm, Annual Ceccil Steiner Memorial Lecture, University of Southern California, 2004. 